\title{
Nutritional and sensory analysis of Parkia Biglobosa (Dawadawa) based cookies
}

\author{
Sackey Augustina Sackle, Kwaw Emmanuel \\ Department of Hotel, Catering and Institutional Management, Cape Coast Polytechnic, Ghana
}

Email address:

sacklesackey@yahoo.com(S. A. Sackle),nyangoahkwaw@yahoo.co.uk(K. Emmanuel)

\section{To cite this article:}

Sackey Augustina Sackle, Kwaw Emmanuel. Nutritional and Sensory Analysis of Parkia Biglobosa (Dawadawa) Based Cookies. Journal of Food and Nutrition Sciences. Vol. 1, No. 4, 2013, pp. 43-49. doi: 10.11648/j.jfns.20130104.13

\begin{abstract}
Consumers demand for quality and nutritious foods is increasing, hence the need for food manufacturers to develop new nutritious and affordable products to meet their increasing demand by combining different ingredients. It is against this background that the study was performed to produce dawadawa based cookies with the view of improving the sensory and nutritional values of the products. In addition to a control sample using only wheat flour, five (5) different ring doughnut formulations were prepared using varying wheat and Parkia biglobosa (dawadawa) flour ratios. Sensory analysis using fifty untrained panel and proximate analyses were performed. The results revealed that greater significant differences in visual puffiness, appearance, texture/mouthfeel, moistness and smell acceptability were not observed among the products. Superimposition of the optimal areas having a score greater than 6.0 from each attribute was done to obtain an optimal formulation range. However, the sensory assessments of the products on the 9-point hedonic scale depicted that in all, product scores were more than 6.8 on the scale which is an indication that all sensory attributes were at least liked moderately in each case by the panel. The results depicted that, there was improvement on the nutritional contents (fat, carbohydrate, ash and fibre) of the formulations as the proximate analysis general showed an increase in value of $27.13 \pm 2.14 \%$ for fat and oil against a control sample of $23.71 \%, 37.24 \pm 3.79 \%$ carbohydrate, $1.40 \pm 0.25 \%$ ash and $2.85 \pm 0.97 \%$ fibre as against control sample of $33.16 \%$ carbohydrate, $0.95 \%$ ash and $0.90 \%$ fibre. However, there was a decrease in the protein content of the formulations (mean value of $10.44 \pm 0.64 \%$ against $17.22 \%$ for the control sample). Panels were able to correctly discriminate between the different samples in terms of the sensory attributes on the 9-point hedonic scale. However, the overall liking of the samples as perceived by the panel indicated that all products were acceptable; with Sample C (Wheat 320g: Dawadawa 80g) being the most preferred. Positive purchase intent was noticed among the panel hence offering new sales potential for the Parkia biglobosa based cookies.
\end{abstract}

Keywords: Parkia Biglobosa Based Cookies, Sensory Attributes, Overall Acceptability, 9-Point Hedonic Scale, Nutritional Values

\section{Introduction}

Consumers demand for quality and nutritious foods is increasing, hence the need for food manufacturers to develop new nutritious and affordable products to meet their increasing demand by combining different ingredients. A typical example of such initiation is the use of leguminous seeds and other cereals because of the high cost of animal proteins and their economic value. This has been demonstrated in the production of cookies such as cake using rice [1].

This research seeks to develop and improve on the nutritional and health benefits of cookies by using wheat and dawadawa flour. Cookies are non-fermented aerated mix variety of flour confectionary products which are eaten as snack or dessert. The fundamental ingredients mostly used in their production include flour, butter, sugar and eggs. Some spices, dry fruits and other flavouring are added to this recipe [2]. It is suitable for special occasions like birthday parties and weeding receptions.

Dawadawa (Parkia biglobosa) is a locust bean which is grown in Southern, Eastern and West Africa. In Ghana, the tree is mostly found in the Northern, Upper East, Upper West and some part of the Southern sector such as Keta Karachi (Volta Region), Ejura (Ashanti Region) and Kwahu (Eastern Region). Parkia biglobosa is a perennial, deciduous tree that ranges in height from $7 \mathrm{~m}$ to $20 \mathrm{~m}$ and bears a large crown with branches that spread wide and which typically are attached low down onto the stout bole. It has brownish grey bark, and longitudinal gaps, green 
leaves at flowering and reddish brown during fruiting stages [3]. The dawadawa seeds are mainly fermented and used for seasoning soups and stews. However, with the advancement in food technology, the seed is recently used for the manufacturing of stock cubes as seasoning. A typical example is Royco dawadawa by Nestle' Ghana limited.

Legumes are consumed worldwide especially in developing and under-developed countries where consumption of animal protein is limited as a result of economic, social and cultural factors [4]. Seed of legumes may account for $80 \%$ of dietary protein and may be the only source of protein for some groups. They are eaten as meals in cooked form and commonly used in fermented form as condiment to enhance the flavour of food $[5,6]$. The fermentation process is by bacterial action which dramatically improves the quality of the beans. This principally makes the proteins in the beans much more digestible [7]. Small quantities of fermented seeds are crumbled into traditional soups and stews during cooking. Due to it savoury taste, high protein and fats content dawadawa is sometimes described as a meat or cheese substitute [8].

In view of its readily availability, nutrition and health benefits, it is important that, dawadawa be incorporated into most of our food products hence this research seeks to use dawadawa to produce ring doughnuts as means of improving the nutritional, sensory and its health benefits.

\subsection{Nutritional Value of African Locust Bean (Parkia Biglobosa)}

The fruit pulp of the African locust bean is sweet which indicates the presence of natural sugars and thus a potential energy source. The attractive yellow colour indicates the presence of phyto-nutrients, possibly carotenoids, which are important precursors of retinol (Vitamin A). It is also a good source of ascorbic acid (Vitamin C) [9]. The bean contents about $67.30 \%$ carbohydrate making it a potential good source of energy [10].

It is a source of dietary fibre which is essential for good bowel movement and helps in preventing obesity, diabetes and cancer of the colon and other ailments of the gastro- intestinal tract of man. The vitamin $\mathrm{C}$ (Ascorbic acid) content in the seed is $(191.20 \mathrm{ug} / 100 \mathrm{~g})$, which is higher than most regularly consumed foodstuff and adequate compared to the recommended daily intake of $30 \mathrm{mg} / 65 \mathrm{~kg}$ body weight adult human [11]. Vitamin $\mathrm{C}$ is very useful in collagen synthesis, facilitates iron absorption and participates in biosynthesis of glucocorticoids.

Table 1. Proximate composition of raw locust bean and dawadawa

\begin{tabular}{ccc}
\hline $\begin{array}{c}\text { Nutritional parameter } \\
(\%)\end{array}$ & Raw locust bean & Dawadawa \\
\hline Moisture content & $7.01 \pm 0.01$ & $37.10 \pm 0.20$ \\
Crude fibre & $4.70 \pm 0.02$ & $2.00 \pm 0.10$ \\
Lipids & $9.57 \pm 0.03$ & $21.17 \pm 0.03$ \\
Crude protein & $28.00 \pm 2.00$ & $38.50 \pm 1.50$ \\
Ash & $2.00 \pm 0.20$ & $1.80 \pm 0.20$ \\
Carbohydrate & $55.73 \pm 0.73$ & $36.53 \pm 0.53$ \\
\hline
\end{tabular}

Values are means of four replicate determinations (Mean $\pm \mathrm{SD}), \mathrm{SD}=$ Standard Deviation Source: [12]

\subsection{Processing Of Dawadawa Fruit into Powder}

In order to get access to the yellowish pulp (fruit) which enclose the dark-coloured seed, thrashing follows immediate after the fruit is sun dried after which it is gently pounded to separate the powder from the seeds without breaking them. A sieve is used to sift, which separates the finest mealy substance (powder) from the seeds. The seeds are further dried to prevent insect attack. Also, the residue after pounding is used to feed domestic stock as well as poultry in some parts of West Africa

The dawadawa powder does not deteriorate rapidly, however, immediate storage is significant in the sense that, it prevents the flour from absorbing moisture from the atmospheric water which makes it mouldy and reduces the shelf life. In spite of the powder not deteriorating rapidly, the mealy substance (powder) is filled and pressed into an earthen ware pot then ash is spread to cover the top in other to prevent weevil, other insects attack and moisture contact. The flour can be stored for a year or more if properly kept.

\subsection{Nutritional Value of Selected Doughnuts}

Table 2. Nutritional rate of selected doughnuts

\begin{tabular}{|c|c|c|c|c|c|c|}
\hline \multirow{2}{*}{ Types of doughnut } & \multicolumn{6}{|c|}{ Per doughnut serving size } \\
\hline & Energy (kCal) & Fat (g) & Saturated fat (g) & Sugar (g) & Salt (g) & Fibre (g) \\
\hline $\begin{array}{l}\text { Ultimate chocolate dream } \\
\text { doughnut }\end{array}$ & 481 & 22.9 & 13 & 34.5 & 0.5 & 3.4 \\
\hline Toffee apple doughnut & 437 & 13.2 & 5.2 & 41.2 & 0.6 & 1.8 \\
\hline Sugar ring doughnut & 135 & 2.7 & 0.9 & 4.2 & 0.3 & 1.1 \\
\hline Strawberry jam doughnut & 214 & 3.8 & 1.2 & 10 & 0.4 & 1.6 \\
\hline Ring chocolate doughnut & 223 & 8.1 & 3.6 & 12.9 & 0.3 & 1.2 \\
\hline Raspberry jam doughnut & 214 & 3.8 & 1.2 & 10 & 0.4 & 1.7 \\
\hline Pink Iced ring doughnut & 261 & 14.2 & 8.6 & 11.5 & 0.3 & 0.8 \\
\hline
\end{tabular}




\begin{tabular}{lcccccc}
\hline \multicolumn{1}{c}{ Types of doughnut } & \multicolumn{5}{c}{ Per doughnut serving size } \\
& Energy (kCal) & Fat (g) & Saturated fat (g) & Sugar (g) & Salt (g) & Fibre (g) \\
\hline Mint fondant doughnut & 199 & 3.8 & 1.2 & 7.6 & 0.4 & 1.6 \\
$\begin{array}{l}\text { Lemon frosted doughnut with } \\
\text { white chocolate curls }\end{array}$ & 394 & 14 & 6.2 & 38.1 & 0.4 & 1.4 \\
Lemon doughnut & 219 & 4.6 & 1.7 & 10.3 & 0.5 & 1.6 \\
\hline
\end{tabular}

Source: [13]

\section{Materials/Equipments and Methods}

\subsection{Material/Equipments}

Wooden spoon, mixing bowl, measuring cup, electronic balance scale (Mark KL30), whisk, baking tin, baking sheet, perforated spoon, pallet knife, oven gloves, skewer, gas oven (Turkna2 Lf559940), ring doughnut baking machine, wheat and dawadawa flour, sugar, margarine, eggs, and baking powder.

\subsection{Methods}

\subsubsection{Dawadawa Flour and Ring Doughnut Preparation}

The harvested fruits were ripped open after which the yellowish pulps was removed from the pods and washed. Pods were then pounded to get the powder and sifted to get the finest powder. The powder was dried in the sun for 48 hours and stored in an air tight container. Ring doughnut recipe as described by [14] was used but the ratio of flours used is shown in Table 3. Flowcharts for the sample preparations are shown below.
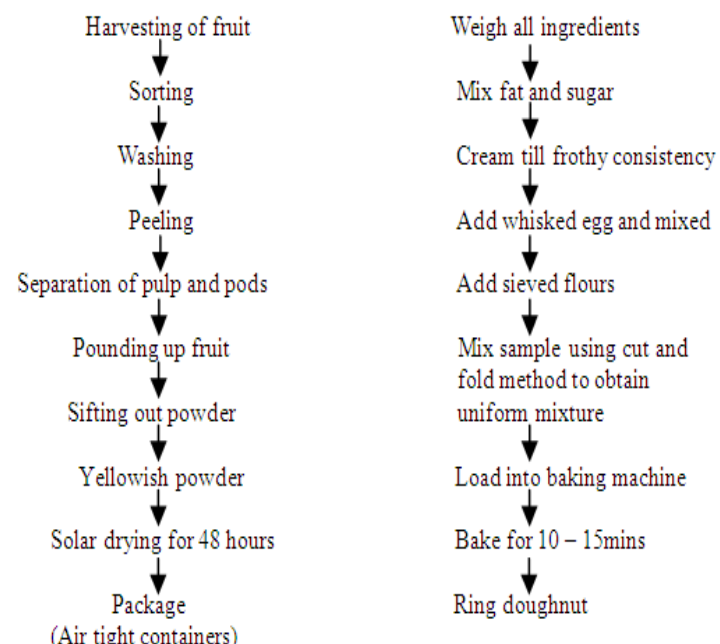

Figure 1. Flowcharts for dawadawa flour and ring doughnut production

Table 3. Ratio of wheat flour to dawadawa flour used

\begin{tabular}{lcc}
\hline \multirow{2}{*}{ Sample Code } & \multicolumn{2}{c}{ Types of flour } \\
& Wheat flour(g) & Dawadawa flour(g) \\
\hline A & 400.0 & 0.0 \\
B & 360.0 & 40.0 \\
C & 320.0 & 80.0 \\
D & 280.0 & 120.0 \\
E & 240.0 & 160.0 \\
F & 200.0 & 200.0 \\
\hline
\end{tabular}

\subsubsection{Sensory Analysis}

Fifty untrained panel were selected for the sensory analysis after their concerns were sought using the Department of Hotel, Catering and Institutional Management Research Consent Form. Their demographic information was gathered using a Sample Survey From. Panel were presented with coded samples (Table 3.0) and water to rinse their mouth after tasting each samples. Each panel evaluated six (6) samples for visual puffiness, appearance/colour, smell/aroma, flavour, taste, overall texture/mouth feel, moistness, and overall liking on a 9point hedonic scale $(1=$ dislike extremely, $5=$ neither like nor dislike, 9=like extremely). Their assessments were then recorded on sensory analysis form. Setup for the sensory analysis is shown below:
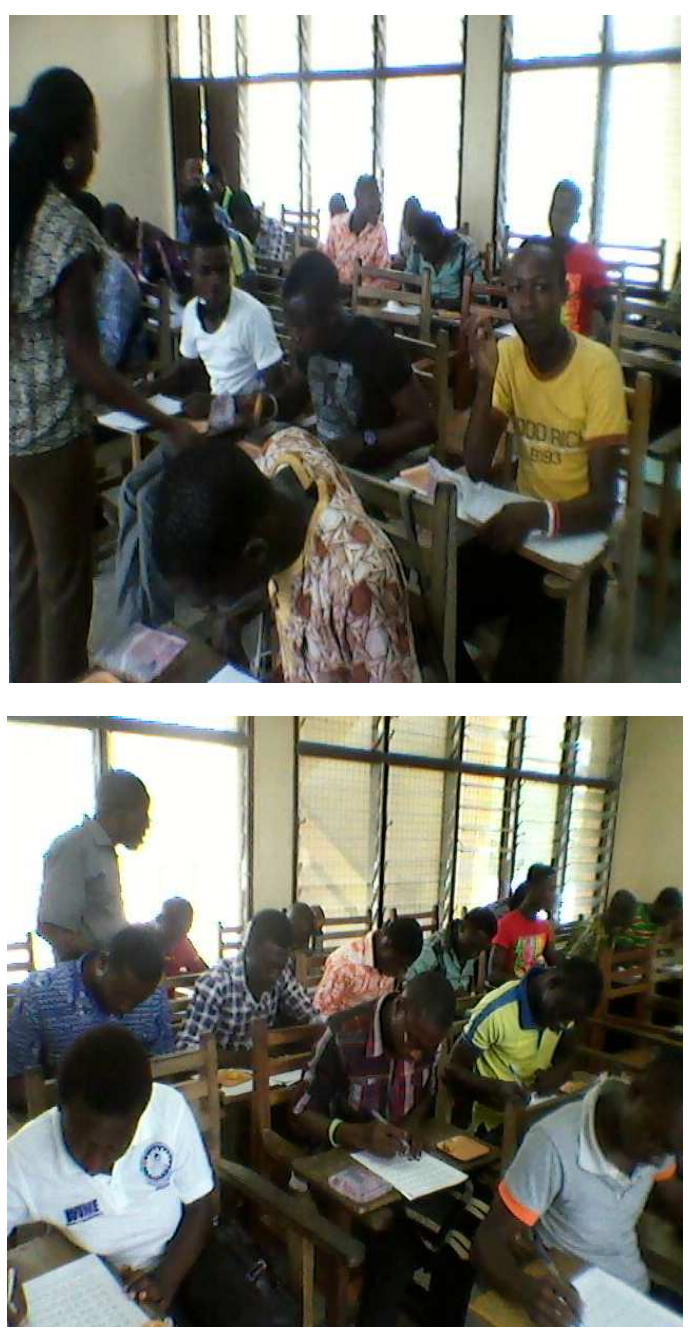

Figure 2. Sensory panel assessing products 


\section{Results and Discussion}

\subsection{Results}

\subsubsection{Proximate Analysis}

Proximate analysis (percent carbohydrate, fat, ash, protein and moisture content) was conducted on each sample using the Association of Official Agricultural Chemists methods as describe by [15].
Table 4. Proximate values of dawadawa based ring doughnut

\begin{tabular}{lll}
\hline Per Serving & & \% Daily value \\
\hline Calories & 396 & \\
Calories from fat & 1916 & \\
Total fat & $212.9 \mathrm{~g}$ & $328 \%$ \\
Carbohydrates & $46.0 \mathrm{~g}$ & $15 \%$ \\
Dietary fibre & $0.0 \mathrm{~g}$ & $0 \%$ \\
Protein & $4.3 \mathrm{~g}$ & \\
\hline
\end{tabular}

Source: [16]

Table 5. Ring Doughnut Nutritional Facts

\begin{tabular}{cccccccc}
\hline Sample & \%Moisture & \% Dry Matter & \% Ash & \% Protein & \% Fat/Oil & \% CHO & \% Fibre \\
\hline A & 16.47 & 83.52 & 0.95 & 17.22 & 23.71 & 33.16 & 0.90 \\
B & 18.28 & 81.71 & 1.11 & 10.88 & 24.54 & 32.68 & 1.72 \\
C & 19.29 & 80.7 & 1.23 & 10.68 & 25.39 & 33.69 & 1.89 \\
D & 18.24 & 81.75 & 1.42 & 10.51 & 27.55 & 38.86 & 3.25 \\
E & 22.51 & 77.47 & 1.46 & 10.8 & 28.48 & 40.01 & 3.65 \\
F & 18.94 & 81.05 & 1.76 & 9.33 & 29.71 & 40.97 & 3.73 \\
Standard deviation & 1.77 & 1.77 & 0.25 & 0.64 & 2.14 & 3.79 & 0.97 \\
Mean values & 19.45 & 80.54 & 1.40 & 10.44 & 27.13 & 37.24 & 2.85 \\
\hline
\end{tabular}

\subsubsection{Demographic Data}

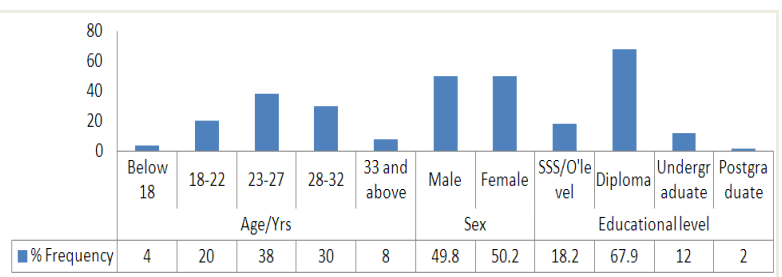

Figure 3. Demographic information of panel

The ages of the panel is shown in Figure 3.0. Out of a panel of fifty, $4 \%$ were below 18 years, $20 \%$ were between the ages of $18-22$ years, $38 \%$ were between the ages of 23 27 years, while 30 and $8 \%$ were between the ages of $28-$ 32 year and above 33 years respectively.

The sex distribution depicted that, $49.8 \%$ were male while 50.2 were female. The educational level of the panel shows that majority $(67.9 \%)$ of the panel were diploma holders. This is because the test was carried in Cape Coast Polytechnic and its environs. Therefore most of the Polytechnic Students (Higher National Diploma) student took part in the assessment.

Panel's response on whether they will purchase and/or consume dawadawa or any dawadawa based product is shown in Figure 4.0. Majority of the panel, $71.43 \%$ and $85.51 \%$ responded that they consume dawadawa products and would purchase dawadawa based ring doughnut respectively.

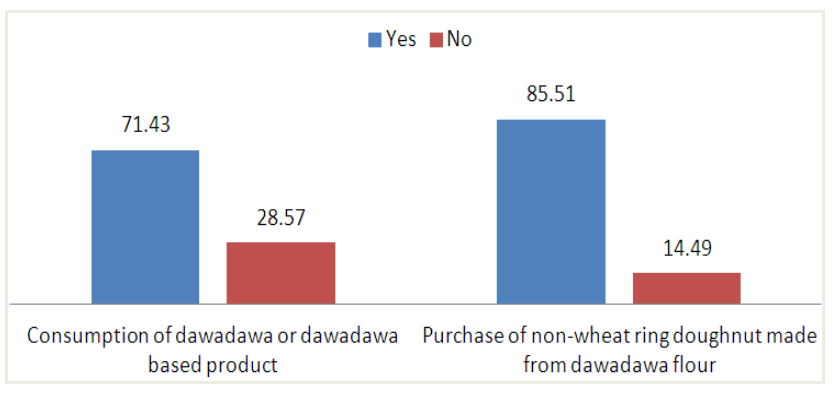

Figure 4. Purchase and consumption of dawadawa or dawadawa based products

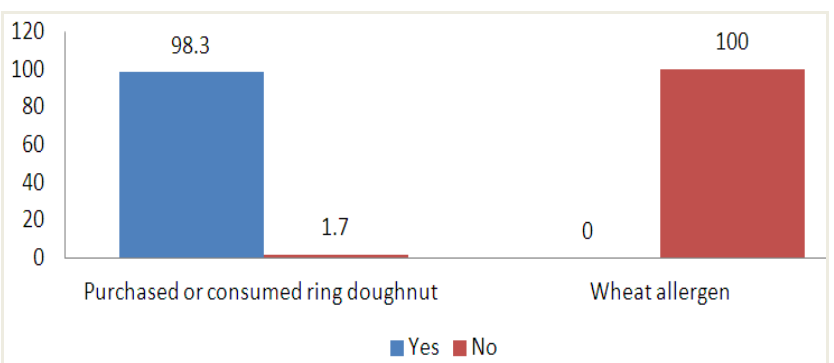

Figure 5. Purchased or consumed of ring doughnut and wheat allergen

The study revealed that the entire panel were not allergic to wheat with majority $(98.3 \%)$ purchase and/or consume ring doughnuts.

The favourite ring doughnut flavour of the panel is as shown in Figure 7.0 and these are chocolate (36.7\%), berry $(30.6 \%)$, and coffee $(8.2 \%)$ whiles $24.5 \%$ like plain (unflavoured) doughnut. 


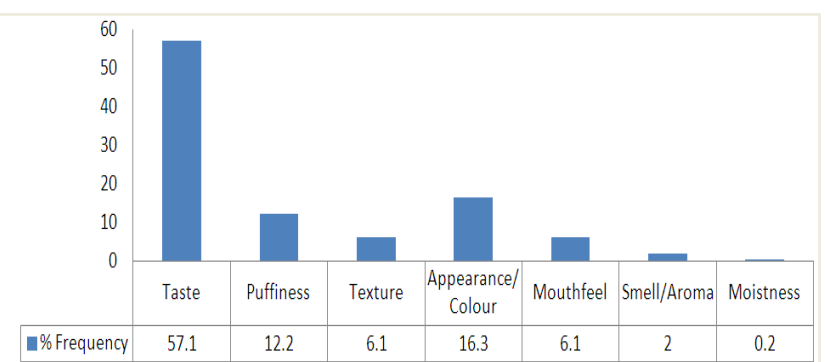

Figure 6. Important sensory attributes panel want in ring doughnut

Figure 6.0 shows the important sensory attributes panel want in a ring doughnut. Most of the panel (57.1\%) suggested taste, whiles $0.2 \%$ suggested moistness, $16.3 \%$ suggested appearance, $12.2 \%$ suggested puffiness, and $6.1 \%$ each suggested mouth feel and texture respectively.

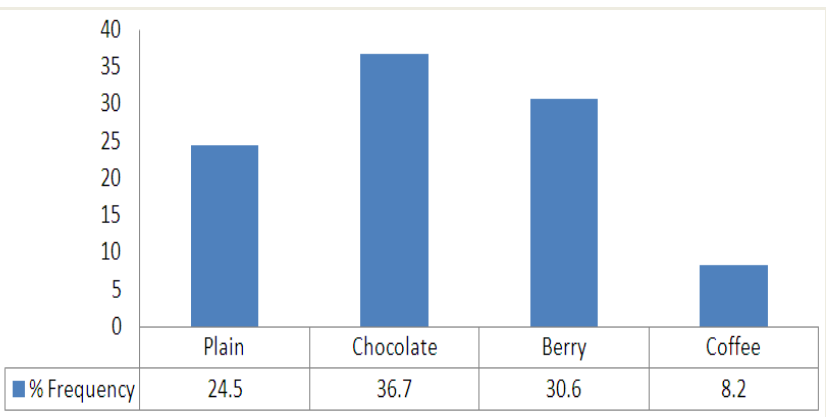

Figure 7. Panel's favourite ring doughnut flavour

\subsubsection{Sensory Assessment of Dawadawa Based Ring Doughnut}

Sensory evaluation of the six (6) samples for visual puffiness, appearance/colour, smell/aroma, taste, overall texture/mouthfeel, moistness, and overall liking on a 9point hedonic scale $(1=$ dislike extremely, $5=$ neither like nor dislike, 9=like extremely) is shown in Table 4.3 illustrating the mean assessment values and standard deviations.

Sensory assessment of the products on 9-point hedonic scale is as shown in Table 6.0. In all products scores were more than 6 on the scale which is an indication that all sensory attributes were at least liked slightly in each case by the panel.

\subsection{Overall Liking of Product}

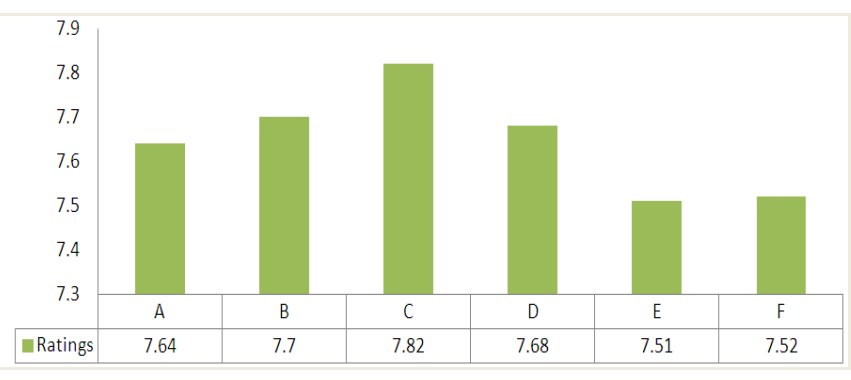

Figure 8. Overall liking of products

Panel assessment on the overall likeness of the products (Figure 8.0) shows that as the ratio of dawadawa to flour increased (Sample A to C (Table 3.)), panel liking also increased. However, when ratios of dawadawa to wheat exceeded 1:2 their likeness decreased gradually.

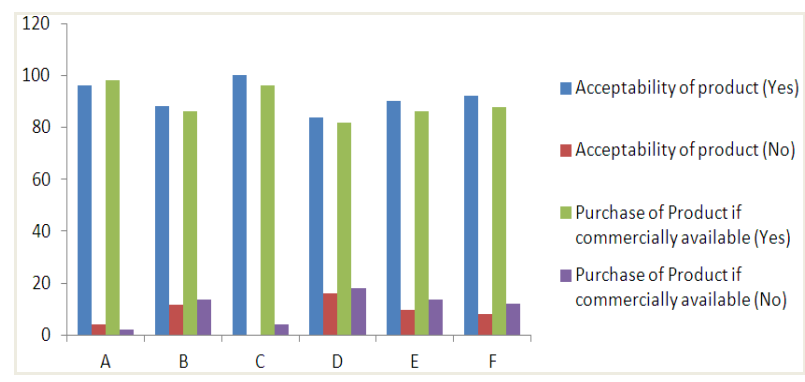

Figure 9. Acceptability and purchase of product on commercial basis

Product assessment, acceptability and whether panel would buy the product if commercially available are shown in Table 7.0 and Figure 9.0. It is observed that $52.1 \%$ of the panel explained that the Sample "A" look sandy. Furthermore, $96.0 \%$ suggested that the Sample " $\mathrm{A}$ " is acceptable. It was found out that $98 \%$ of the panel would buy the Sample if it was available commercially, but $2 \%$ would not buy the products if they were commercially available. It was observed that more than half $(64.0 \%)$ of the panel explained that the Sample B do not look sandy. Nevertheless, $82.2 \%$ suggested that the Sample B is acceptable. The results also revealed that $86.3 \%$ of the panel would buy the Sample B if it was available commercially, but $13.7 \%$ would not buy the Sample B.

Table 6. Sensory Assessment

\begin{tabular}{ccccccccccccc}
\hline \multirow{2}{*}{ Sensory attributes } & \multicolumn{2}{c}{ Sample A } & \multicolumn{2}{c}{ Sample B } & \multicolumn{2}{c}{ Sample C } & \multicolumn{2}{c}{ Sample D } & \multicolumn{2}{c}{ Sample E } & \multicolumn{2}{c}{ Sample F } \\
& Mean & SD & Mean & SD & Mean & SD & Mean & SD & Mean & SD & Mean & SD \\
\hline Visual Puffiness & 7.80 & 0.83 & 7.53 & 1.06 & 7.84 & 0.82 & 7.34 & 1.69 & 7.45 & 1.53 & 7.56 & 1.67 \\
Appearance/Colour & 7.44 & 1.15 & 7.06 & 1.55 & 7.80 & 0.95 & 7.22 & 1.73 & 7.37 & 1.37 & 7.48 & 1.71 \\
Smell/Aroma & 7.88 & 0.96 & 7.65 & 1.09 & 7.72 & 0.83 & 7.44 & 1.50 & 7.49 & 1.45 & 7.58 & 1.53 \\
Taste & 7.82 & 1.02 & 7.69 & 1.19 & 7.80 & 0.88 & 7.48 & 1.55 & 7.61 & 1.51 & 7.66 & 1.38 \\
Overall Texture/Mouth feel & 7.66 & 0.92 & 7.67 & 1.09 & 7.86 & 0.81 & 7.14 & 1.58 & 7.59 & 1.39 & 7.68 & 1.41 \\
Moistness & 7.44 & 1.11 & 7.49 & 1.27 & 7.60 & 0.90 & 6.88 & 1.79 & 7.16 & 1.71 & 7.62 & 1.26 \\
Overall liking & 7.64 & 0.82 & 7.70 & 1.14 & 7.82 & 0.90 & 7.68 & 1.81 & 7.51 & 1.41 & 7.46 & 1.46 \\
\hline
\end{tabular}


Table 7. Product Assessment

\begin{tabular}{|c|c|c|c|c|c|c|c|c|c|c|c|c|}
\hline \multirow{3}{*}{ Product Assessment } & \multicolumn{2}{|c|}{ Sample A } & \multicolumn{2}{|c|}{ Sample B } & \multicolumn{2}{|c|}{ Sample C } & \multicolumn{2}{|c|}{ Sample D } & \multicolumn{2}{|c|}{ Sample E } & \multicolumn{2}{|c|}{ Sample F } \\
\hline & YES & NO & YES & NO & YES & NO & YES & NO & YES & NO & YES & NO \\
\hline & $\begin{array}{l}\text { Row } \\
\text { N \% }\end{array}$ & $\begin{array}{l}\text { Row } \\
\text { N \% }\end{array}$ & $\begin{array}{l}\text { Row } \\
\text { N \% }\end{array}$ & $\begin{array}{l}\text { Row } \\
\text { N \% }\end{array}$ & $\begin{array}{l}\text { Row } \\
\text { N \% }\end{array}$ & $\begin{array}{l}\text { Row } \\
\text { N \% }\end{array}$ & $\begin{array}{l}\text { Row } \\
\text { N \% }\end{array}$ & $\begin{array}{l}\text { Row } \\
\text { N \% }\end{array}$ & $\begin{array}{l}\text { Row } \\
\text { N \% }\end{array}$ & $\begin{array}{l}\text { Row } \\
\text { N \% }\end{array}$ & $\begin{array}{l}\text { Row } \\
\text { N \% }\end{array}$ & $\begin{array}{l}\text { Row } \\
\text { N \% }\end{array}$ \\
\hline Sandy & 47.9 & 52.1 & 36.0 & 64.0 & 34.0 & 66.0 & 48.0 & 52.0 & 24.0 & 76.0 & 16.0 & 84.0 \\
\hline $\begin{array}{l}\text { Is this Product } \\
\text { Acceptable }\end{array}$ & 96.0 & 4.0 & 88.2 & 11.8 & 100.0 & 0 & 84.0 & 16.0 & 90.2 & 9.8 & 92.0 & 8.0 \\
\hline $\begin{array}{l}\text { Purchase of product if } \\
\text { commercially available }\end{array}$ & 98.0 & 2.0 & 86.3 & 13.7 & 96.0 & 4.0 & 82.0 & 18.0 & 86.3 & 13.7 & 88.0 & 12.0 \\
\hline $\begin{array}{l}\text { If Allergic to Wheat, } \\
\text { would buy the product }\end{array}$ & 100.0 & 0 & 92.2 & 7.8 & 98.0 & 2.0 & 90.0 & 10.0 & 88.2 & 11.8 & 90.0 & 10.0 \\
\hline
\end{tabular}

Although more than half (66\%) of the panel explained that Sample C was not sandy, the results (Figure 9.0) also depicted that, all $(100.0 \%)$ the panel suggested that Sample $\mathrm{C}$ was acceptable and that $96.0 \%$ of the panel would buy the Sample $C$ if it was available commercially.

The result also showed that less than half (48\%) of the panel explained that the Sample D was sandy but surprisingly, $84.0 \%$ of the panel suggested that the Sample $\mathrm{D}$ is acceptable and that would buy the Sample if it was available commercially. The results also showed that more than half (76.0\%) of the panel suggested that the Sample E was sandy. However, $90.2 \%$ of the panel suggested that Sample E was acceptable but $86.3 \%$ of the panel would buy if it was available commercially. More than half $(84.0 \%)$ of the panel explained that the Sample F was not sandy with $92.0 \%$ of the panel suggested that the Sample F was acceptable but $88.0 \%$ of the panel would buy the Sample F if it was available commercially.

\section{Discussions}

Consumers demand for quality and nutritious foods is increasing, hence the need for food manufacturers to develop new nutritious and affordable products to meet their increasing demand by combining different ingredients. The need for flours that are free of gluten (such as millet, tapioca, potato, soy, flax, etc.) is becoming progressively more popular in the mainstream supermarket, therefore offering new sales potential for food companies [17]. It is against this background that the study was performed to produce dawadawa based ring doughnut with the view of improving the sensory and nutritional values of the products.

The nutritional analysis (Figure 5.0) shows that, as the ratio of wheat to dawadawa flour decreased, all nutrients value of the products except that of protein increased which depicts that the addition of dawadawa did improve nutritional values of the ring doughnuts compared to the control Sample A. The proximate analysis general showed an increase in value of $27.13 \pm 2.14 \%$ for fat and oil against a control sample of $23.71 \%, 37.24 \pm 3.79 \%$ carbohydrate,
$1.40 \pm 0.25 \%$ ash and $2.85 \pm 0.97 \%$ fibre as against control sample of $33.16 \%$ carbohydrate, $0.95 \%$ ash and $0.90 \%$ fibre. However, there was a decrease in the protein content of the formulations (mean value of $10.44 \pm 0.64 \%$ against $17.22 \%$ for the control sample). The locust bean is a good source of thiamine, vitamin $\mathrm{C}$, riboflavin and protein [12, $18,19]$ however, the decrease in protein might be due to factor(s) during production and proximate analysis. It is however worth knowing that comparing the protein content of the dawadawa based ring doughnut (Table 6.0) to that of wheat ring doughnut nutritional facts (Table 3.0), that of the dawadawa based ring doughnut was high.

Greater significant differences in visual puffiness, appearance, texture/mouthfeel, moistness and smell acceptability were not observed among the products (Figure 9.0). Superimposition of the optimal areas having a score greater than 6.0 from each attribute was done to obtain an optimal formulation range. However, the sensory assessments of the products on the 9-point hedonic scale as shown in Table 6.0 depicts that in all, products scores were more than 6.8 on the scale which is an indication that all sensory attributes were at least liked moderately in each case by the panel. Although [20] stated that when gluten is removed from bakery products, it negates the desired qualities but this was not so with the ring doughnut which shows improved nutritional (Table 6.0) and sensory qualities as the amount of dawadawa flour increased. Hence the notion that, most gluten-free products currently available on the market are of inferior quality to those containing gluten [21] may not be so. Panel assessment on the overall likeness of the products (Figure 8.0) shows that as the ratio of dawadawa flour to that of wheat flour increases (Sample A to C), panel liking also increased. However, when the amount wheat to dawadawa flour decreased (Sample D to F) their likeness decreased. Their overall likeness as shown in Figure 8.0 show that consumers liked Sample C (Wheat (320g): dawadawa $(80 \mathrm{~g})$ ). Logistic regression analyses identified overall liking, taste, aroma and texture as attributes critical to overall acceptance and purchase decision. These attributes served as factors in obtaining the optimal formation range since 
panel indicated taste as the most important sensory attribute they want in their ring doughnut. The product assessment, acceptability and whether panel would buy product if commercially available as shown in Figure 9.0 indicated that all products were acceptable to most of the panels and that would buy products if commercially available.

\section{Conclusion}

There was improvement on the nutritional contents of the formulation as the proximate analysis general showed an increase in value from the control Sample (A). Panels were able to correctly discriminate between the different samples in terms of the sensory attributes on the 9-point hedonic scale. However, the overall liking of the samples as perceived by the panel indicated that all products were acceptable with Sample C being the most preferred. Positive purchase intent was noticed among the panel hence offering new sales potential for the dawadawa based ring doughnut.

\section{References}

[1] Bond, A.E. (2004) Consumer sensory characteristics of butter cake made from wheat and rice flours. Master of Science dissertation, Louisiana State University

[2] Welsby, J. B., Tomlinson, H. F., Oni, P. I., Buchy, M. and Aebischer, D. P. (1993). (Parkia biglobosa) a monograph. School of Agricultural and Forest Sciences Publication No 9, University of Wales, Bangor, United Kingdom.

[3] Leaky, L. A., Kessler, J. J. and Slingerlands, M. (1999) Pruning of nere trees (Parkia biglobosa) Berth on the farmlands of Burkina Faso, Agroforestry Systems, 33: 8798.

[4] Esenwal, A and Ikenbomeh, H. (2008). Diversity and Use of Palms in Zahamena, Eastern Madagascar. Biodiversity and Conservation, 10:951-970.

[5] Odunfa, S. A., Oyewole, O. B. (1998) Africa fermented foods. In: Microbiology of Fermented Foods. $2^{\text {nd }}$ Ed. Vol. 2. London, Blackie Academic and Professional.

[6] Achi, O. K. (2005) The potential for upgrading traditional fermented foods through biotechnology. African Journal of Biotechnology. 4:5, 375-380
[7] Lloyd, A. S. (2005). (Parkia biglobosa) Leguminosae in West Africa: Biosystematics improvement. $\mathrm{PhD}$ thesis, Agricultural University of Wageningen

[8] Lamien, O.U. (2001). Effect of fermentation on the nutrient status of locust beans. Food Chem., 5: 305-308.

[9] Akoma, D. A., Akinsulire, O. R. and Sanyaolu, M. A (2001) Qualitative determination of chemical and nutritional composition of Parkia biglobosa. Afr. J. Biotechnol., 4: 812815.

[10] Uwaegbute, A. (1996) Foods: Facts and Principle. Willey Eastern Ltd; New Delhi

[11] Olson, J.A and Hodges, R.E. (1987) Recommended dietary intake of vitamin $\mathrm{C}$ in Humans. American J. Clin. Nutri. 45: 693Chukwu et al., 2010

[12] Nutritional

information. URL:http://www.morrisons.co.uk/MarketStreet/NutritionalI $\mathrm{n}$ formation $/$ ?type $=12$ \& category $=$ Bakery + and + Morning + Goo ds\&OrderBy=Product Name\&action=desc [15/06/2013]

[13] Campbell, J., Koskett, D and Paskins, P. (2012) Practical cookery for NVQ and apprenticeship. London, UK. Hodder Education.

[14] Nielsen, S. S. (2010) Food analysis. Fourth edition. New York, USA. Springer Science+Business Media

[15] URL:http://www.caloriescount.about.com/calories-waitrosering-doughnut-i73792.

[16] Turcsik, R. 2004. Flour power. Supermarket Grocery Business.

[17] Steinkraus, K. H. Editor, (2000). Handbook of indigenous fermented foods.2nd edition. Marcel Dekker, New York.

[18] Chukwu, O., Orhevba, B. A and Mahmood, B, I (2010) Influence of Hydrothermal Treatments on Proximate Compositions of Fermented Locust Bean (Dawadawa). Journal of Food Technology, 8:(3): 99-101

[19] Gallagher, E., Gormley, T. R. and Arendt, E. K. (2004) Recent advances in the formulation of gluten-free cerealbased products. Trends in Food Science \& Technology. 15:143-152.

[20] Arendt, E. K., O’Brien, C. M., Schober, T. J., Gallagher, E. and Gormley, T. R. (2002) Development of Gluten-Free Cereal Products. Farm \& Food. Summer: 21-27. 